\title{
Pharmacognostic Profile of Ageratum conyzoides L Plant and Simplicia
}

\author{
Warsinah*, Hanif Nasiatul Baroroh
}

\section{Warsinah*, Hanif Nasiatul}

Baroroh

Department of Pharmacy, Faculty of Health

Sciences, University of Jenderal Soedirman, Purwokerto, Central Java, INDONESIA.

\section{Correspondence \\ Warsinah}

Department of Pharmacy, Faculty of Health Sciences, University of Jenderal Soedirman, Purwokerto, Central Java, INDONESIA.

E-mail: warsinahapt@gmail.com History

- Submission Date: 16-01-2020;

- Review completed: 10-02-2020;

- Accepted Date: 08-06-2020.

DOI : 10.5530/pj.2020.12.151

Article Available online

http://www.phcogj.com/v12/i5

\section{Copyright}

(C) 2020 Phcogj.Com. This is an openaccess article distributed under the terms of the Creative Commons Attribution 4.0 International license.

\begin{abstract}
Ageratum conyzoides Linn. is known as billy goat weed, including the family Asteraceae. This plant has been used empirically as a medicine for diarrhea, scratches, antinflammatory, snakebite, insecticide and nemasiticide. This study aims to identify plants based on pharmacognitive profiles including macroscopy, microscopy and non-parametric characters from plant parts of ageratum conyzoides to determine the standardization of herbs. The results showed that the leaves were ovoid, pale green, soft hairy and purple, bluish or white flowers flowers. Microscopic observations of cross section of stem and leaf showed the presence of parenchyma cells, collenchyma cells and multicellular non-glandular trichomes, upper and lower epidermal cells, stomata in the upper and lower epidermis of the leaf. The highest value of water content was in the radix. The highest value of ash content was in the stem. The highest value of acid soluble ash content was in the radix. The highest value of water-soluble extract was in the folium. The highest value of ethanol-soluble extract was in the flower. The results of this study can be used as authentication of plant parts and a basis for the analysis of the standard pharmacopoeia A. conyzoides.
\end{abstract}

\section{INTRODUCTION}

The development of study on medicinal plants is growing rapidly. Especially the development of pharmacology and phytochemicals study based on indications of medicinal plants that have been used by some people with empirically tested properties. Many plants are considered as raw material for medicine so it is recommended for therapeutic use. ${ }^{1}$ The use of plants as traditional medicines and alternative medicines is increasingly in demand because it is relatively safer compared to synthetic drugs. It needs many studies to develop plant properties with various methods such as the study of ethnomedicine or ethnobotany, bio essay, and purification of bioactive compounds. Increasing the need for medicinal plants by the pharmaceutical industry and its own needs by $5-18 \%$ per year ${ }^{2}$

The Asteraceae family consists of 1500 genera and 2500 different species. ${ }^{3}$ Ageratum is one of the genera included in the Asteraceae family and consists of 30 species. ${ }^{4}$ Ageratum conyzoides is called goatweed ${ }^{5}$ and has been empirically used as a drug to treat boils and fever medications. ${ }^{6} \mathrm{~A}$. conyzoides is a tropical plant commonly found in the western and eastern regions of the African continent, in several regions of Asia and South America. The plant is a polymorphic aromatic weed. The leaves of Ageratum conyzoides are used as wounds therapy, ${ }^{7}$ hemorrhoids, anti-dysentery, antibacterial, ${ }^{8}$ anti-inflammatory, analgesic, antipyretic, antispasmodic, gastroprotective, antiulcer, insecticide, ${ }^{9}$ antihelmintic and antimosquito. The results showed that many plants were recommended for medicinal purposes. ${ }^{1}$ The use of plants for medicinal purposes and research can be used as a basis for reference in the discovery of active compounds as drugs. The recommendation is based on secondary metabolites produced by plants as natural organic chemical compounds. ${ }^{10}$ Based on the content of chemical compounds in plants such as terpenoids, alkaloids, flavonoids, tannins, saponins, and steroids whose quality and quantity are sufficient so that they can promise therapeutic efficacy of medicinal plants. ${ }^{4}$ Natural organic compounds can be used as marker compounds either in the synthesis or semi-synthesis processes so that they play an important role in the discovery and development of drugs based on therapeutic targets. Incorrect identification of natural products or herbal medicines causes its use is also wrong, ${ }^{10}$ for example, the existence of vernacular names given to two or more completely different species. All of these problems can be solved by pharmacognostic studies in plants.

\section{MATERIALS AND METHODS}

\section{Plant materials}

Ageratum conyzoides plants were collected from around the campus of Jenderal Soedirman University in Purwokerto. The plant was identified by plant taxonomists from Faculty of biology. The result of plant identity was validated by the dean of the faculty of biology with certificate number 1264/UN.23.02.8/ TA.00.01 / 2019.

\section{Macroscopic analysis}

Fresh plants and simplicia were observed and performed organoleptically including shapes, colors, odors, tastes, surfaces, characters, textures, and bedding. 


\section{Microscopic analysis}

Microscopic analysis was determined by preparing a thin section crosssection of leaves and stems. The incision was placed on a glass object and drops of water and covered with a deck glass then observed under a microscope with magnification (40X,100X). Cells such as epidermal (cells upper and lower), xylem, phloem, collenchyma, and parenchyma were observed. All images were seen photographed and recorded for further analysis.

\section{Examination of non-specific characters}

\section{a. Drying shrinkage examination}

One gram of powder that placed into a porcelain crucible has been preheated at $105^{\circ} \mathrm{C}$ for 30 minutes and has been tamed. The powder was flatten in crushed porcelain. Then the powder was put into the oven, heated at a temperature of $105^{\circ} \mathrm{C}$ for 1 hour, removed and cooled in a desiccator. The results were weighed until a fixed weight and the dry weight was obtained.

$$
\% \text { Drying Shrinkage }=\frac{\text { Wet weight- } \text { dry weight }}{\text { Wet weight }}
$$

\section{b. Ash content analysis}

One gram of powder was put into porcelain crucifix. The powder was put into a furnace temperature of $600^{\circ} \mathrm{C}$ for 6 hours, put in the desiccator and weighed. Then the ash of the dried material content was determined.

$$
\% \text { Ash content }=-------\times 100 \%
$$$$
\text { B-A }
$$

Information:

$\mathrm{A}=$ Crucible weight empty

$\mathrm{B}=$ Crucible weight + sample before incubation

$\mathrm{C}=$ Crucible weight + sample after incubation

\section{c. Determination of ash content which is not soluble in acid}

The powder was boiled with $25 \mathrm{ml}$ of dilute sulfuric acid for 5 minutes. The acid-insoluble portion was collected, filtered through an ash-free filter paper which was not soluble in acid to the dried material.

\section{d. Determination of water soluble essence}

Simplicia powder was weight carefully about $5 \mathrm{~g}$. The powder was put in a clogged pumpkin, added of $100 \mathrm{~mL}$ of saturated chloroform water, shaked repeatedly for the first 6 hours, then settled down for 18 hours and then filtered. The filtrate of $20 \mathrm{~mL}$ was evaporated and then dried in a shallow cup that has been heated $105^{\circ}$ and tapped. The remainder was heat at $105^{\circ}$ until fixed weight. The value of $\%$ water-soluble extracts was determined.

\section{e. Determination of ethanol soluble extract}

Five gram of powder was put in the clogged pumpkin, added $100 \mathrm{~mL}$ of $95 \%$ ethanol, shaked repeatedly for the first 6 hours and settled down for 18 hours. The mixture was quick filtered to avoid ethanol evaporation. The filtrate of $20 \mathrm{~mL}$ was dried in a shallow flat-bottomed dish that has been heated $105^{\circ}$, tamed, and heat the remainder at $105^{\circ}$ until the fixed weight. The value of $\%$ ethanol-soluble extract was determined.

\section{f. Specific gravity}

Sample of extract as much as $1 \%$ was diluted with ethanol in a pycnometer. The pycnometer was calibrated by setting the weight of the pycnometer and the weight of the water which heated at $25^{\circ} \mathrm{C}$.

Temperature that used was set at around $20^{\circ} \mathrm{C}$. Sample of extract were put in a pycnometer with a temperature of $25^{\circ} \mathrm{C}$. The excess of liquid extract was removed and weighed. Specific gravity of extract was calculated employing the weight of the dilute extract divided by the weight of the extract and the weight of water. ${ }^{11}$

\section{g. Identification of chemical compounds in A conyzoides}

Identification of essential oils using the steam distillation method, while for other compounds using chemical reagents such as $\mathrm{FeCl} 3$ to determine tannins, $\mathrm{HCl} 2 \mathrm{~N}$ to determine saponins, Yodine $0.1 \mathrm{~N}$ to find carbohydrates and glycosides with $\mathrm{FeCl} 3$ and $\mathrm{HCl}$ addition. This chemical reagent will give a distinctive color or precipitate according to compounds contained in plants.

\section{RESULT}

\section{Macroscopic analysis}

Ageratum conyzoides is a species that belongs to the family Asteraceae. This plant is a weed that grows wild, can be found around houses, gardens, and bushes. The performed organoleptically of plant including shapes, colors, odors, tastes, surfaces, characters, textures, and bedding were shown in Table 1 and Figure 1. The characteristics of plant was purple, bluish or white flowers. As shown in Figure 1, characteristic of A.conyzoides leaf was pale green, aromatic odor, spicy taste, hairy on both sides with cuneate base, 30-70 cm height, petiole 1.1-1.5 cm long and egg-shaped with the wide end at the base (ovoid) (Figure 1). We found the shape of A.conyzoides root was soft hairy (Table 1).

\section{Microscopic analysis}

Characteristics of fresh plants on the cross-section of the trunk were showed the presence of epidermis, collenchyma reinforcement tissue, sclerenchyma reinforcement tissue, parenchyma, transport beam, trichome gland (Figures 2 and 3), whereas trichome and stomata glands were found in leaves (Figures $3 \mathrm{c}$ and $3 \mathrm{~d}$ ). There were tissue fragments such as parenchymal tissue, parenchyma phloem, cork, trichome, mesophyll, parenchyma cortex, fibers, amylum, secretion cells and stomata in simplicia (Figures 3a and 3b).

\section{Table 1: Macroscopical characters of the leaves of Ageratum conyzoides.}

\begin{tabular}{cc}
\hline The size of Leaf & $4.4-5.2 \times 3.2-4.3 \mathrm{~cm}$ \\
Leaf color & Pale green \\
Leaf shape & Egg round (ovoid) \\
The Aroma of leaves & Aromatic \\
Root shape & Soft hairy \\
Plant & Bush \\
\hline
\end{tabular}

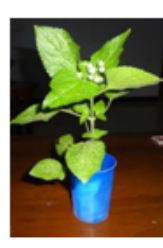

1
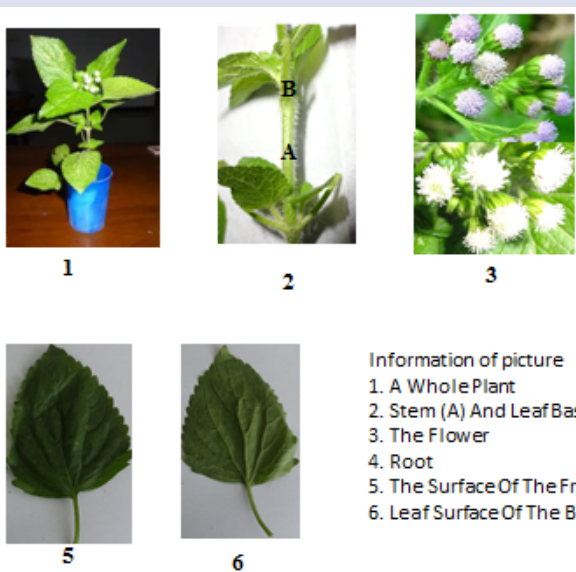

3

2
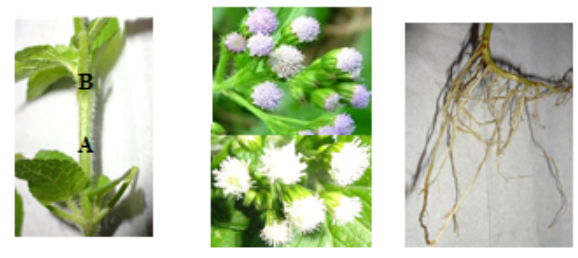

Information of picture

1. A Whole Plant

2. Stem (A) And Leaf Base (B)

3. The Flower

4. Root

5. The Surface Of The Front Leaves

6. Leaf Surface Of The Back

Figure 1: Profile Macroscopical of fresh plant of Ageratum conyzoides. 


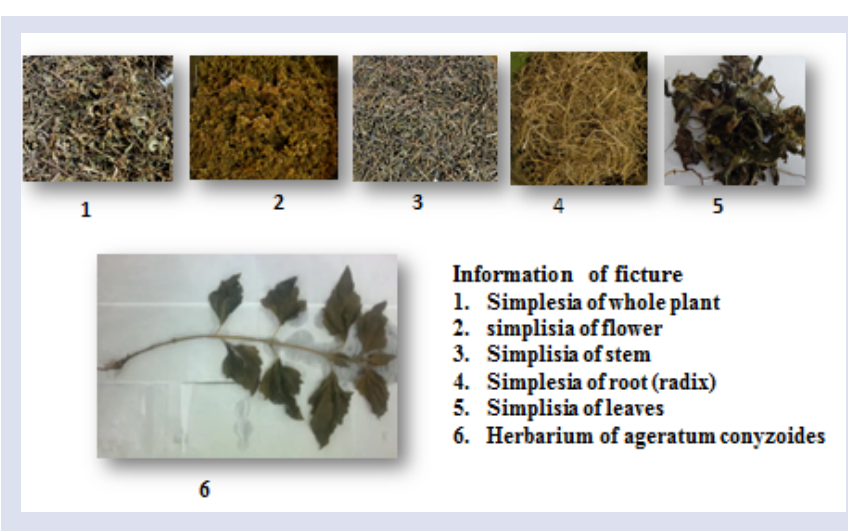

Figure 2: Profile Macroscopical of simplicia of Ageratum conyzoides.

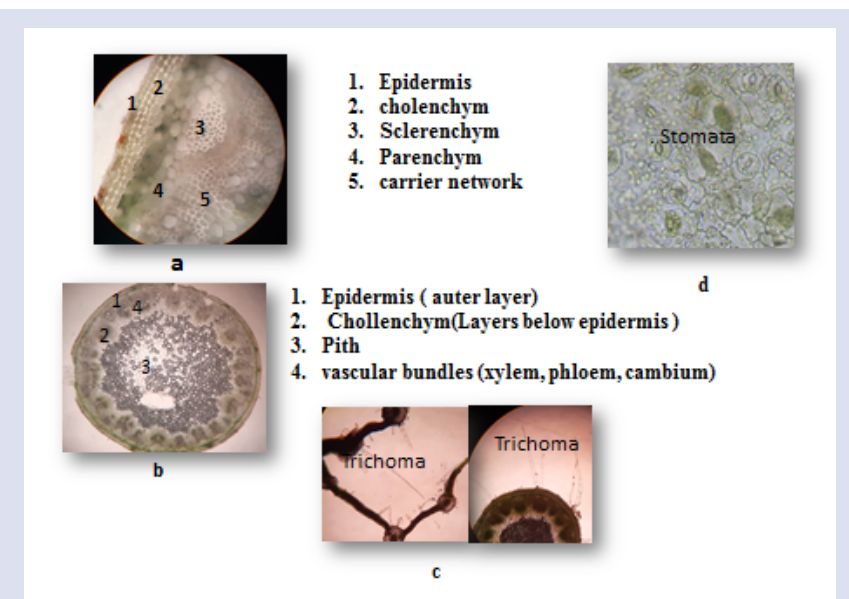

Figure 3: Profile Microscopic of Ageratum conyzoides leaves.

\section{Determination of quality of simplicia}

Results of the Simplicia powder characterization including determination of water content, determination of total ash content and acid insoluble ash content, determination of drying losses and determination of water-soluble and ethanol extracts are presented in Table 2. Simplicia characterization of A.conyzoides was evaluated to determine simplicia specifications and clarify of the material under study because the origin of the growing environment affected the content of active compounds. As shown in Table 2, the highest value of water content was in the radix. The highest value of ash content was in the stem. The highest value of acid soluble ash content was in the radix. The highest value of water-soluble extract was in the folium. The highest value of ethanol-soluble extract was in the flower.

\section{Determination of the specific gravity of extract}

Powder of simplicia was extracted by maceration method using ethanol $96 \%$ for $3 \times 24$ hours. The filtrate was collected and evaporated with an evaporator and the value of yield was calculated (Table 3 ). The specific gravity of extract on the roots, leaves, stems and flowers of $A$. conyzoides, each with the same specific gravity, while the highest yield is in the leaves.

\section{Identification of chemical compounds of Ageratum conyzoides}

Chemical constituent studies are supporting data on pharmacognitive profiles. In this study identification was carried out using chemical reagents that can change color or precipitate formation in accordance with the character of chemical compounds contained in the sample (Table 4). This research helps determine the compounds that are efficacious in plants. The compounds identified in A conyzoides are essential oils, tannins, saponins, carbohydrates and glycosides (Table 4).

\section{DISCUSSION}

Identification is an inseparable part of the standardization of medicinal ingredients. ${ }^{12}$ Before the ingredients are put in Herbal Pharmacopeia, pharmacognostic standards and quality of Simplicia must be specified. Macroscopy standards, microscopy, and quality of Simplicia can be used as an identification parameter to authenticate medicines. ${ }^{13}$ The Macroscopic character from the factory is very needed for the source of diagnostic parameters. ${ }^{14}$ The microscopic method is one of the simple and inexpensive methods. This method can be used to identify plant specimens. Previous studies of leaf cross-sections have been reported. Standardization becomes an important measure to determine the quality, quantity, purity, and authenticity of plants. ${ }^{14}$ Similarly, macroscopic observations of leaf characters such as color, odor, taste, margins, base, tops and so on can help the identification of Ageratum conyzoides plants. Microscopic evaluation can be noticed trichomes, collenchyma, and parenchyma, xylem, and phloem. ${ }^{15-19}$ Stomata can also be seen clearly. microscopic Simplicia observation also shows the presence of tissue fragments such as trichome, cork, starch, etc. This study can also help in plant identification.

\section{CONCLUSION}

Results of this study can be concluded that information about the quality of drug raw materials can be obtained from the macroscopic analysis, microscopy, and simplicia quality parameters. Identification of Ageratum conyzoides with these parameters can be obtained with

Table 2: Determination of quality of simplicia of Ageratum conyzoides based on non-specific characters.

\begin{tabular}{|c|c|c|c|c|}
\hline \multirow{2}{*}{ Parameters } & \multicolumn{4}{|c|}{ The value (\% b/b) } \\
\hline & flower & Stems & folium & Radix \\
\hline Water content & $8.23 \pm 3.24$ & $8.83 \pm 2.95$ & $8.46 \pm 3.92$ & $8.92 \pm 3.16$ \\
\hline Total ash content & $1.61 \pm 0.61$ & $1.78 \pm 0.53$ & $1.58 \pm 0.42$ & $1.58 \pm 0.42$ \\
\hline $\begin{array}{l}\text { Acid insoluble ash } \\
\text { content }\end{array}$ & $3.89 \pm 0.18$ & $3.59 \pm 0.48$ & $4.59 \pm 0.78$ & $5.98 \pm 0.57$ \\
\hline Moisture content & $4.21 \pm 0.16$ & $4.21 \pm 0.26$ & $6.21 \pm 0.36$ & $5.21 \pm 0.31$ \\
\hline $\begin{array}{c}\text { Ethanol extract } \\
\text { levels }\end{array}$ & $9.28 \pm 0.39$ & $9.08 \pm 0.29$ & $8.78 \pm 0.69$ & $8.67 \pm 0.68$ \\
\hline Drying shrinkage & $15.33 \pm 3.32$ & $14.24 \pm 3.32$ & $15.42 \pm 3.42$ & $14.98 \pm 3.22$ \\
\hline
\end{tabular}

Table 3: The result of determining the specific gravity.

\begin{tabular}{cccc}
\hline Plant parts & $\begin{array}{c}\text { Weight extract } \\
(\mathbf{g})\end{array}$ & Yield (\%) & Specific gravity \\
\hline stems & $8.23 \pm 3.24$ & 8.72 & 0.800 \\
folium & $8.92 \pm 3.44$ & 12.8 & 0.800 \\
radix & $8.22 \pm 3.04$ & 7.80 & 0.800 \\
flower & $8.86 \pm 2.94$ & 8.24 & 0.800 \\
\hline
\end{tabular}

Table 4: The content chemical of Ageratum conyzoides.

\begin{tabular}{|c|c|c|c|c|c|}
\hline \multirow[b]{2}{*}{ No } & \multirow[b]{2}{*}{ Identification } & \multirow[b]{2}{*}{ Reagen } & \multicolumn{2}{|c|}{ Colour } & \multirow[b]{2}{*}{ Information } \\
\hline & & & $\begin{array}{c}\text { Before } \\
\text { reagent }\end{array}$ & $\begin{array}{c}\text { After } \\
\text { reagent }\end{array}$ & \\
\hline 1 & essential oil & $\begin{array}{c}\text { steam } \\
\text { distillation }\end{array}$ & green & green & + \\
\hline 2 & tannin & $\mathrm{FeCl}_{3}$ & $\begin{array}{l}\text { brownish } \\
\text { green }\end{array}$ & black blue & + \\
\hline 3 & saponin & $\mathrm{HCl}(2 \mathrm{~N})$ & & bubbly & + \\
\hline 4 & karbohidrat & Yodine & $\begin{array}{l}\text { brownish } \\
\text { green }\end{array}$ & $\begin{array}{l}\text { brick red } \\
\text { sediment }\end{array}$ & + \\
\hline 5 & glikosida & $\begin{array}{c}\mathrm{FeCl}_{3} \text { dan } \\
\mathrm{HCl}\end{array}$ & $\begin{array}{l}\text { brownish } \\
\text { green }\end{array}$ & $\begin{array}{l}\text { brownish } \\
\text { green }\end{array}$ & + \\
\hline
\end{tabular}



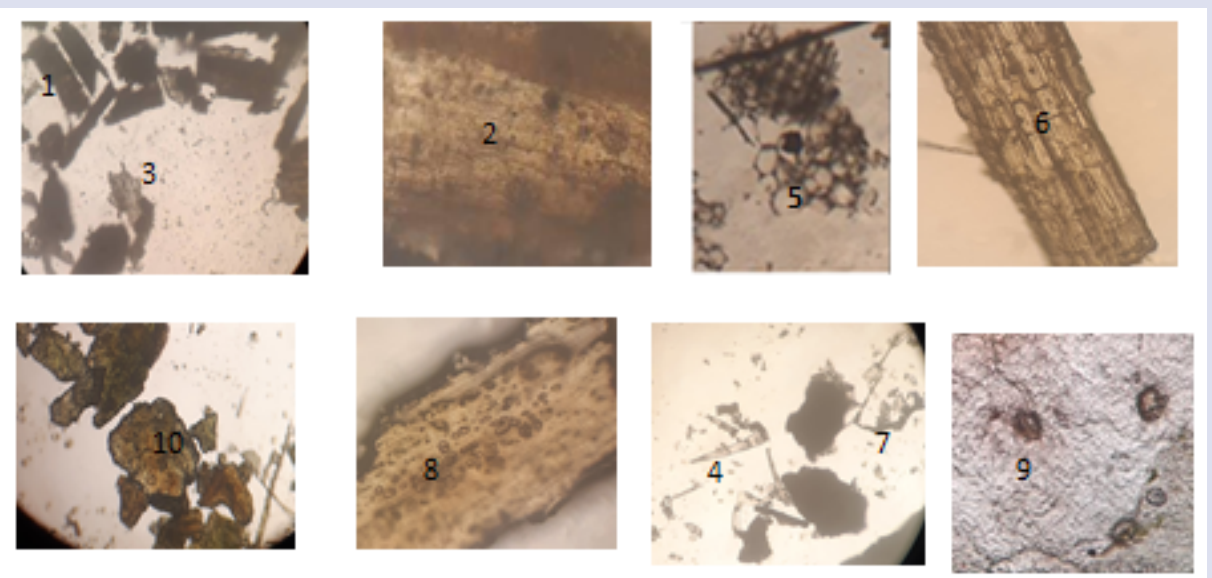

Information

\section{Parenchymal tissue, 2. Parenchyma phloem,3. Cork 4. Trachoma, 5. Mesophyll, 6. Parenchyma cortex, 7 fibers, 8. Amylum, 9. Cell secretion. 10. Stomata.}

Figure 4: Profile Ageratum conyzoides simplistic tissue fragments.

morphological, pharmacognostic and quality of simplicia information. It can be used to find the authentication of species and genus of plants and used to ensure quality control of medicinal plants.

\section{ACKNOWLEDGMENT}

The author would like to thank the Directorate of Higher Education Kemenristekdikti for funding this research through Higher Education Applied Research 2019.

\section{REFERENCES}

1. Khare, C.P. (2007). Indian Medicinal Plants: An Illustrated Dictionary. Allahabad (India): Lalit Mohan Basu.

2. Kohler, J.C. \& Baghdadi-Sabeti, G. 2011. The World Medicines Situation, 3rd Ed, World Health Organization.

3. Souza, V.C., Lorenzi, H., 2012. Botânica sistemática: guia ilustrado para identificac, ãodas famílias de fanerógamas nativas e exóticas no Brasil, baseado em APG III.Instituto Plantarum, Nova Odessa.

4. Okunade, A.L. (2002). Ageratum conyzoides L. (Asteraceae). Fitoterapia 73: $1-16$

5. Bosi, C.F., Rosa, D.W., Grougnet, R., Lemonakis, N., Halabalaki, M., Skaltsounis, A.L., \& Biavatti, M.W. (2013). Pyrrolizidine alkaloids in medicinal tea of Ageratum conyzoides. Brazilian Journal of Pharmacognosy 23(3): 425-432.

6. Silalahi, M. (2014). The ethnomedicine ofthe medicinal plants in sub-ethnic Batak, North Sumatra and the conservation perspective, dissertation. Indonesia: Universitas Indonesia.

7. Dash, G.K., Murthy, P.N. (2011a). Wound healing effects of Ageratum conyzoides Linn. Int J Pharm Bio Sci., 2 (2): 369-383.

8. Woldeyes, S., Adane, L., Tariku, Y., Muleta, D., Begashaw, T. (2012). Evaluation of antibacterial activities of com-pounds isolated from Sida rhombifolia Linn. (Malvaceae). Nat Prod Chem Res; 1(101):2.
9. Moreira, M.D., Picanço, M.C., Barbosa, L.C.A., Guedes, R.N.C., Barros, E.C. Campos, M.R. (2007). Compounds from Ageratum conyzoides: Isolation, structure elucidation and insecticidal activity. Pest Manag Sci., 63 (6): 615621

10. Chintoju, N., Konduru, P., Kathula, R.L., Remella, R. (2015). Importance of natural products in the modern history. Research and Reviews: Journal of Hospital and Clinical Pharmacy, 1(1):5-10.

11. Anam, S., Muhammad, Y., Alfred, T., Nurlina, I., Ahmad, K., Ramadanil, Sulaiman, Z. 2013.

12. Periyanayagam, K., Karthikeyan, V. (2013). Pharmacognostical, SEM and XRF profile of the leaves of Arto-carpu sheterophyllus L. (Moraceae) - A contribution to combat the NTD. Innovare Journal of Life sciences, 1 (1): 23-28.

13. Department Kesehatan RI, 2000. Parameter Standar Umum Ekstrak Tumbuhan Obat.

14. Kaur, R., Singh, B., Kaur, S. (2018). Pharmacognostic stud-ies on leaves of Ageratum conyzoides Linn. Journal of Pharmacognosy and Phytochemistry; 7(3):3181-3185.

15. Santos, R.F., Nunes, B.M., Sá, R.D., Soares, L.A.L., \& Randau, K.P. (2016) Morpho-anatomical study of Ageratum conyzoides. Revista Brasileira de Farmacognosia 26: 679-687.

16. Standarisasi Ekstrak Etil Asetat Kayu Sanrego (Lunasia amara Blanko), Online Journal of Natural Science, Vol 2(3): 01-08.

17. Folashade, K.O., Omoregie, E.H. and Ochogu, A.P. 2012. Standardization of herbal Medicines-A Review. Int. J.Biodiv. Conserv. 4: 3.

18. Noura, A.M.M., Khalid, S.A., Kaiser, M., Brun, R., Abdalla, W.E., \& Schmidt T.J. (2010). The antiprotozoal activity of methylated flavonoids from Ageratum conyzoides L. Journal of Ethnopharmacology 129: 127-130.

19. Nyunaï, N., Njikama, N., Abdennebic, E.H., Mbaford, J.T., \& Lamnaouer, D. (2009). Hypoglycaemic and antihyperglycaemic activity of Ageratum conyzoides L. in rats. Afr. J. Trad. CAM. 6(2): 123-130. 


\section{GRAPHICAL ABSTRACT}

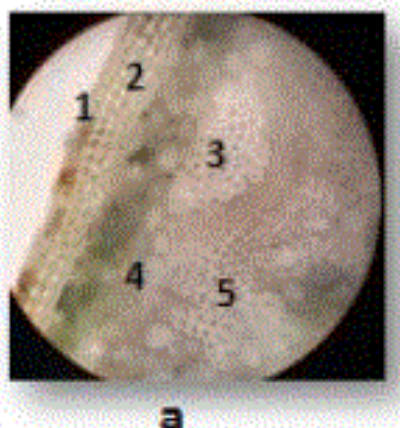

\section{Epidermis}

2. cholenchym

3. Sclerenchym

4. Parenchym

5. carrier network

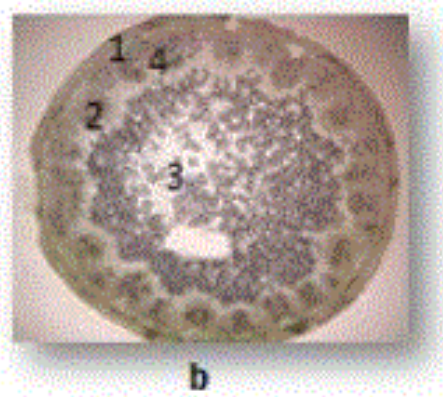

1. Epidermis ( auter layer)

2. Chollenchym(Layers below epidermis)

3. Pith

4. vascular bundles (xylem, phloem, cambium)

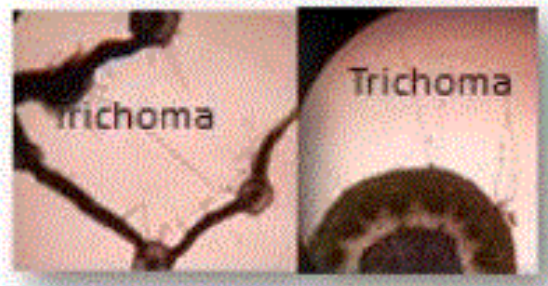

C

\section{ABOUT AUTHORS}

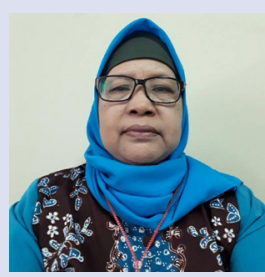

Warsinah Is a lecturer of Pharmacy Departement, Faculty of Health Sciences, Jenderal Soedirman University. Undergraduate education, pharmacist and post-graduate (S3) at Gadjah Mada University, while post-graduate (S2) at Sebelas Maret University. This author actively conducts research on pharmacognosy and phytochemistry.

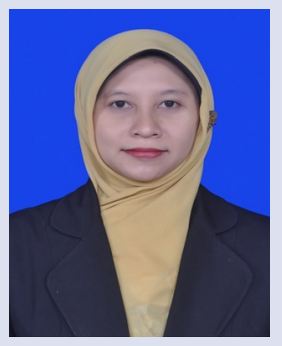

Hanif Nasiatul Baroroh Undergraduate education program, Pharmacist and Masters in pharmacy at Gadjah Mada University. This author is actively conducting research into drug discovery from plants and pharmacology activity including inflammation, arthritis, allergies and has produced 2 patents on Psidium guajava leaves for anti-allergies and the ethanol extract of Jatropha curcas leaves for anti- arthritis.

Cite this article: Warsinah, Baroroh HN. Pharmacognostic Profile of Ageratum conyzoides L Plant and Simplicia. Pharmacogn J. 2020;12(5):1072-6. 